\title{
Dynamic linkage between real exchange rates and stock prices: Evidence from developed and emerging Asian markets ${ }^{1}$
}

\author{
By \\ Tomoe Moore \\ Economics and Finance \\ Brunel University \\ Uxbridge \\ Middlesex, UB8 3PH \\ United Kingdom \\ E-mail: tomoe.moore@brunel.ac.uk \\ Tel: +44189526 6642 \\ Fax: +441895269770 \\ and \\ Ping Wang \\ Birmingham Business School \\ University of Birmingham \\ Edgbaston, Birmingham B15 2TT \\ United Kingdom \\ Email: p.wang.1@bham.ac.uk \\ Tel: +441214146675 \\ Fax: +441214146238
}

\footnotetext{
1 This is a revised version of the paper presented at the Asian Finance Association International Conference, held at Hong Kong in July, 2010. Thanks are due to the participants of this conference for their helpful comments. The authors are also grateful to the editor and two anonymous referees for their useful and constructive comments and suggestions. The usual disclaimer applies.
} 


\begin{abstract}
This paper investigates the sources of the dynamic relationship between real exchange rates and stock return differentials in relation to the US market for the developed and emerging Asian markets. We, first, derive the dynamic conditional correlation (DCC) of the two series, and then DCC is regressed on the trade balance and the interest rate differentials. In general, the trade balance is found to be a main determinant of the dynamic correlation for the Asian markets, whereas the interest rate differential is the driving force for the developed markets. The latter seems to reflect the high capital mobility.
\end{abstract}

Keywords: Real exchange rates; Stock return differentials; Dynamic conditional correlation; trade balance; interest rate differentials

JEL Classification: C22, G15 


\section{Introduction}

During the past decade, a growing literature has emerged in an attempt to explore the relationship between exchange rates and stock prices, see, for example, Abdalla and Murinde (1997), Ajayi et al (1998), Granger, et al. (2000), Smyth and Nandha (2003) Phylaktis and Ravazzolo (2005),Moore (2007a and 2007b) and Pan et al. (2007). Empirically, the presence of a significant relationship between the two variables is found elsewhere. For example, Hatemi-J and Irandoust (2002) report that the Granger causality is unidirectional, running from stock prices to exchange rates, and an increase in Swedish stock prices is found to be associated with an appreciation of the Swedish Krona. Moore (2007b) finds a cointegration relationship between stock prices and exchange rates for Poland and Hungary by taking into account the potential structural breaks in the two markets. See also Bahmani-Oskooee and Sohrabian (1992) and Nieh and Lee (2001) for the cointegration approach. Other studies include Malliaropulos (1998), who examined the link between international stock return differentials and deviation from relative purchasing power parity (PPP) for four major OECD countries using the VAR approach. The volatility spillovers between stock returns and changes in exchange rates are examined in the work of Kanas (2000).

There are, inter alia, two strands of classical theories suggesting a relation between stock prices and exchange rates. 'Flow-oriented' models of exchange rates focus on the current account or the trade balance, and assert that the currency movement will affect the international competitiveness and the balance of trade position, which in turn affects the country's real income/output and therefore stock prices (Dornbusch and Fischer 1980). This is based on the traditional macroeconomic view. On the other hand, 'stock-oriented' models of exchange rates, or portfolio balance approaches, predict that the innovations in the stock price affect exchange 
rates via the capital account (Branson 1983 and Frankel 1983): the performance of the stock market may affect the demand for money, with the subsequent changes in interest rates causing exchange rates to appreciate or depreciate.

The relationship between the two series has been theoretically and empirically established, however, the issue of driving forces behind the linkage remains to be unexplored.

This paper aims at investigating the dynamic relation between exchange rates and stock prices and exploring the sources behind the linkage. A two-step estimation procedure is employed. In the first procedure, we derive the dynamic conditional correlation (DCC) advanced by Engle (2002) of the two series, and in the second step, a linear regression model is specified, where the estimated DCC is regressed on the potential determinants of the correlation. Our sample countries include the emerging Asian countries of Indonesia, Malaysia, South Korea, the Philippines, Singapore and Thailand $^{2}$, and the developed countries of Australia, Canada, Japan and the UK for the sample period from 1970s and 1980s to 2006. A relatively wider set of countries may serve to provide an unbiased insight into the inquiry of the relationship between the stock prices and exchange rates.

There are a number of important contributions to the literature. Firstly, the technique of dynamic correlation demonstrates a more direct indication of interdependence between stock and foreign exchange markets, where the dynamics of correlation are modelled together with those of the volatility of the series. ${ }^{3}$ In order to

\footnotetext{
${ }^{2}$ Several studies established the linkage between stock prices and exchange rates for the Asian countries (see Abdalla and Murinde 1997, Ajayi et al 1998, Granger, et al 2000 and Smyth and Nandha 2003, Phylaktis and Ravazzolo 2005 and Pan et al 2006).

${ }^{3}$ Forbes and Rigobon (2002) argue that the cross market correlation coefficients are conditional on market volatility, and if such a test is not adjusted for heteroskedasticity, the estimated correlation coefficients can be biased.
} 
examine varying degrees of relationship, previous studies normally partition the sample period into different phases according to structural changes. Such a subjective designation of cut-off dates may not effectively describe the evolution of the changes on financial markets over time. By accounting for the time-varying conditional correlation of data series, possible changes in conditional correlations can be detected when the state of the economy changes over time, and that this is a rigorous approach in examining the fast-moving volatile stock and foreign exchange markets of the emerging economies. ${ }^{4}$

Secondly, correlation tests are conducted for the variables of real exchange rates and the stock price differentials against the US market. It is argued that much empirical study tends to omit the US stock market, despite the fact that it represents the influence of world markets, and that it has been shown that the results of some of the previous studies are invalid (Caporale and Pittis 1997). Phylaktis and Ravazzolo (2005) found that it acts as a conduit through which the real exchange rate affects the stock market or vice versa. Thirdly, the paper clarifies the theoretical issues of the relationship by assuming that both real exchange rates and stock price differentials contain permanent and temporary components (Huizinga 1987, Fama and French 1988, Poterba and Summers 1988 and Baxter 1994). The theoretical model, which largely follows that of Malliaropulos (1998), predicts a negative relationship.

The fourth contribution, which is the primal objective of this paper, is to investigate the determinants of the dynamic link between the two series. In a linear regression framework, the potential determinants as regressors are explicitly specified.

\footnotetext{
${ }^{4}$ The methodology has been utilised for financial analysis, see for example, Chiang, et al (2007) and Wang and Moore (2008) for the study of stock market contagion and comovements, and also Bautista (2006) for the investigation of the relationship between exchange rates and interest rate differentials in six East Asian countries.
} 
We consider the trade balance and the interest rate differentials as possible determinants of the linkage. The variable of trade balance is deemed to capture the extent of the open characteristics of these economies in terms of exports and imports with the US. Hence if the variable strongly impact on the correlation, economic integration may matter for the linkage. Given that of interest rate differentials, the degree of capital market integration between these countries and the US is gauged as a channel to the correlation of stock and foreign exchange markets. If this effect is significant, financial integration plays a major role for the linkage. The former is based on the traditional macroeconomic view (or the flow-oriented model), while the latter is associated with the portfolio balance model (or the stock-oriented model). The inclusion of the mature financial markets may provide a useful comparative study with the emerging Asian markets, where foreign capital restrictions tend to be prevalent. In this respect, our study may shed a new light on the debate of the two theories by addressing the sources of the correlation in a rigorous empirical framework.

The overall results are summarised as follows. We find a negative dynamic relationship between the relative stock prices and real exchange rates, being consistent with the model prediction. A linear regression model reveals that the trade balance is, in general, the main source of the dynamic correlation for the Asian countries, whereas the interest rate differential is a contributory factor for Australia, Canada and the UK. This appears to suggest that in countries with a relatively low degree of capital mobility, economic integration is likely to the main force of the linkage, supporting the flow-oriented model, whereas in countries with the high capital mobility, financial integration is the main driving force, supporting the stock-oriented model. When, the Asian markets are modelled in the post-Asian crisis period as a subsample period, the driving force slants to the interest rate differentials. This is 
indicative of the improved capital mobility after the crisis for the Asian emerging market.

The paper is organised as follows. Section 2 is for theoretical underpinning, Section 3 is the model specification of the DCC from the GARCH model, and Section 4 describes data. Section 5 presents the result of the DCC estimation, which forms a first part of the empirical procedures, and the linear regression, the second part, is modelled in Section 6. Conclusions are found in Section 7.

\section{Theoretical underpinning}

Following Malliaropulos (1998), we derive a theoretical model of the relationship between the real exchange rate and the stock return differentials between two countries. All variables are in logarithm.

We define the relative stock price between the domestic and foreign countries expressed in the home currency:

$$
\rho_{t}=s_{t}-s_{t}^{*}-e_{t}
$$

where $s_{t}=$ the domestic stock price, $s_{t}^{*}=$ the foreign stock price and $e_{t}=$ a number of domestic currency per unit of foreign currency. The real exchange rate is defined as: $q_{t}=e_{t}+p_{t}^{*}-p_{t}$

where $p_{t}=$ the domestic price, $p_{t}^{*}=$ the foreign price. It is assumed that the real exchange rate is composed of permanent $\left(q_{t}^{P}\right)$ and temporary $\left(q_{t}^{T}\right)$ factors (Huizinga 1987 and Baxter 1994):

$q_{t}=q_{t}^{P}+q_{t}^{T}$

where $q_{t}^{P}=\mu+q_{t-1}^{P}+\varepsilon_{t}^{P}$ and $q_{t}^{T}=\theta q_{t-1}^{T}+\varepsilon_{t}^{T}$. 
The permanent component is specified as a random walk process with a drift, $\mu$, and serially uncorrelated innovations $\varepsilon_{t}^{P}$, whereas the temporary component follows a first order autoregressive process with $0<\theta<1$ plus serially uncorrelated innovations $\varepsilon_{t}^{T}$. Similarly, the relative stock price is assumed to contain both permanent and temporary components, $\rho_{t}^{P}$ and $\rho_{t}^{T}$ respectively (Fama and French 1988 and Poterba and Summers 1988).

$\rho_{t}=\rho_{t}^{P}+\rho_{t}^{T}$

where $\rho_{t}^{P}=v+\rho_{t-1}^{P}+\eta_{t}^{P}$ and $\rho_{t}^{T}=\phi \rho_{t-1}^{T}+\eta_{t}^{T} . \quad 0<\phi<1$

$\eta_{t}^{P}$ and $\eta_{t}^{T}$ are serially uncorrelated innovations. We also assume that $\eta_{t}^{P}$ and $\eta_{t}^{T}$ are uncorrelated with $\rho_{t}^{P}$ and $\rho_{t}^{T}$. The expected changes in the real exchange rate and stock price differential may be defined as:

$E_{t-1} \Delta \rho_{t}=E_{t-1} \Delta\left(s_{t}-s_{t}^{*}-e_{t}\right)$

$E_{t-1} \Delta q_{t}=E_{t-1} \Delta\left(e_{t}+p_{t}^{*}-p_{t}\right)$

where $E_{t-1}=$ expectations formed at time $t-1$ given all available information. Equation (5) may be analogous to the Uncovered Interest Parity applied to stock returns with a risk premium, where the risk premium $E_{t-1} \Delta \rho_{t}$ may contain both a foreign exchange risk and a relative stock return risk. The foreign exchange risk is one of the main risk factors in international equity investment. Equation (6) implies the expected deviation from relative PPP.

We introduce the real stock return differential as given by

$$
\Delta z_{t}=\Delta\left(s_{t}-p_{t}\right)-\Delta\left(s_{t}^{*}-p_{t}^{*}\right)
$$

Adding (5) and (6), and re-rearranging with expectations, we have

$$
E_{t-1} \Delta \rho_{t}=E_{t-1} \Delta z_{t}-E_{t-1} \Delta q_{t}
$$


This equation states that the expected stock return differential is equal to the expected real stock return differential minus the expected change in the real exchange rate. The unobservable expected change can be substituted with a temporary component of the series, hence from Equations (3b) and (4b) we derive the following expressions respectively

$$
\begin{aligned}
& E_{t-1} \Delta q_{t}=\mu+(\theta-1) q_{t}^{T} \\
& E_{t-1} \Delta \rho_{t}=v+(\phi-1) \rho_{t}^{T}
\end{aligned}
$$

The expected real depreciation is associated with the temporary component of the real exchange rate, whereas the expected risk premium is related to the temporary components of the stock price differential. By substituting equations (9) and (10) into (8), we obtain

$$
\rho_{t}^{T}=-(\mu+v) /(\phi-1)-\{(\theta-1) /(\phi-1)\} q_{t}^{T}+\{1 /(\phi-1)\} E_{t} \Delta z_{t}
$$

The equation (11) characterises the dynamic relationship. Since the parameters of the autoregressive terms is $0<\theta<1$ and $0<\phi<1$, the temporary component of the relative stock price is more likely to be negatively correlated to temporary deviations of the real exchange rate from PPP. A negative relationship means that as stock prices increase (decreases), there would be a real appreciation (depreciation) of exchange rates $^{5}$

The dynamic movement may be explained in the context of the monetary sector, and the negative prediction is consistent with the view of the portfolio

\footnotetext{
${ }^{5}$ Empirical results are quite mixed with the sign and causal direction between exchange rates and stock prices. A significant positive relationship is empirically found in the study of Smith (1992), whereas Soenen and Hennigar (1988) find a negative relationship. Loudon (1993) finds that when currency appreciates, industrial stocks (manufacturing and service industries) perform better whilst resource stocks perform better with currency depreciation for Australian firms. Malliaropulos (1998) finds a negative relationship between the two variables for the UK, Japan, France and Germany during the period 1973:1 to $1992: 3$.
} 
approach to exchange rate determination (Phylaktis and Ravazzolo, 2005). Agents allocate their wealth amongst a range of financial assets including money, deposits, bonds, equities and foreign assets. An increase in the stock market raises the value of equities, increasing the total wealth. With an assumption of homogeneity ${ }^{6}$, this raises the demand for each of these assets including money. An increase in the demand for money will cause interest rates to go up and there may be a substitution from foreign securities to domestic assets resulting in an appreciation of the domestic currency. Also, with a rise in the local stock market, foreign investors are attracted to investing into the local market pushing up the demand for the local currency, causing an appreciation of exchange rates. By definition, this effect implies a rise in $\rho_{t}$, and a fall in $q_{t}$, forming a negative correlation between the two series.

In the real sector, the association of the two series can not be based on the dynamic components due to the sluggishness of real economy. It is, however, noted that if $q_{t}$ has a property of mean-reverting, then a real depreciation above its trend level predicted by the permanent component i.e. $q_{t}>q_{t}^{P}$, produces expectations of appreciation (Malliaropulos 1998) ${ }^{7}$. This would cause a loss of competitiveness in an exporting country, though the extent of this depends on whether the Marshal-Lerner holds or not in the economy. If the perception of a mean-reverting nature of real exchange rates is strong amongst investors, domestic stock prices could be dampened relative to the foreign stock market, since the stock prices reflect the expected future cash flows in firms. This means a fall in stock prices in response to a real

\footnotetext{
${ }^{6}$ The wealth homogeneity implies that any shift in an asset's share in the desired equilibrium is due to movements either of yields or of other explanatory variables, not due to the change in total wealth.

${ }^{7}$ For example, Huizinga (1987) and Chen and Tran (1994) find that real exchange rates follow a mean reversion towards PPP.
} 
depreciation, leading to a negative correlation. It is also noted that if changes in real depreciation are positively correlated with the expectations of inflation, and if inflation affects stock returns negatively, then the consequence is a negative correlation. This effect could be strong in countries, which are prone to higher rates of inflation.

\section{DCC model specification}

The bivariate GARCH model with dynamic conditional correlation (DCC) specification (Engle, 2002) is utilized to investigate the relationship between stock price differentials, $\rho_{t}$, and real exchange rates, $q_{t}$. Let $y_{t}=\left[y_{1 t}, y_{2 t}\right]^{\prime}$ be a $2 \times 1$ vector containing the stock price differentials and real exchange rate series in a conditional mean equation as follows,

$y_{t}=\mu+\varepsilon_{t} \quad$ and $\quad \varepsilon_{t} \mid \xi_{t-1} \sim N\left(0, H_{t}\right)$

where $\mu$ is a $2 \times 1$ vector of constant and $\varepsilon_{t}=\left[\varepsilon_{1 t}, \varepsilon_{2 t}\right]$ is a vector of innovations conditional on the information at time $t-1\left(\xi_{t-1}\right)$. The error term is assumed to be conditionally multivariate normal with mean zero and variance-covariance matrix as $H_{t}=D_{t} C_{t} D_{t}$

where $D_{t}$ is a $2 \times 2$ diagonal matrix of the time varying standard deviations from univariate GARCH models with $\sqrt{h_{i, t}}$ on the $i^{\text {th }}$ diagonal. $C_{t}$ is a $2 \times 2$ time-varying symmetric conditional correlation matrix.

As indicated, the elements in $D_{t}$ follow the univariate GRACH process of the following,

$h_{i, t}=\omega_{i}+\alpha_{i} \varepsilon_{i, t-1}^{2}+\beta_{i} h_{i, t-1}$ 
where $\omega_{i}$ is a constant term, $\alpha_{i}$ captures the $\mathrm{ARCH}$ effect, i.e. conditional volatility and $\beta_{i}$ measures the persistent of the volatility. The evolution of the correlation in the DCC model is given as

$Q_{t}=\left(1-q_{a}-q_{b}\right) \bar{Q}+q_{a} \varepsilon_{t-1} \varepsilon_{t-1}^{\prime}+q_{b} Q_{t-1}$

where $Q_{t}=\left\{q_{i j}\right\}_{t}$ is a $2 \times 2$ conditional variance-covariance matrix of residuals with its time-invariant variance-covariance matrix $\bar{Q}=E\left(\varepsilon_{t} \varepsilon_{t}^{\prime}\right)$, and $q_{a}$ and $q_{b}$ are nonnegative scalar parameters satisfying $q_{a}+q_{b}<1$. Because $Q_{t}$ in (15) does not have unit diagonal elements, it is then scaled to get a proper correlation matrix $C_{t}$,

$C_{t}=\operatorname{diag}\left(Q_{t}\right)^{1 / 2} Q_{t} \operatorname{diag}\left(Q_{t}\right)^{-1 / 2}$

A typical element of $C_{t}$ has the form of $\rho_{i j}=q_{i j, t} / \sqrt{q_{i i, t} q_{j j, t}}, i, j=1,2$ and $i \neq j$, which is the key element in this methodology, as it represents the conditional correlation between stock price differentials and real exchange rates.

\section{Data}

The datasets used in this study are the monthly closing stock price indices and end-ofperiod nominal exchange rates, relative to the US dollar, for the countries of Indonesia, Malaysia, South Korea, the Philippines, Singapore and Thailand, representing the Asian emerging markets, and Australia, Canada, Japan and the UK for the developed markets.

We examine the stock prices and exchange rate correlation under a floating exchange rate regime. So the starting date for the four developed markets is from January 1973. For the six Asian emerging markets, the starting date for each country depends on when a floating or managed floating regime was adopted together with the consideration of data availability. Specifically, the starting date is 1983:5 for 
Indonesia, 1980:1 for Korea, 1980:1 for Malaysia, 1986:2 for the Philippines, 1979:1 for Singapore and 1979:1 for Thailand. All the data end in December 2006. The real exchange rate is calculated as the nominal exchange rate adjusted for the domestic and foreign price levels, measured by the respective consumer price indices. The stock price differentials are constructed by converting the US stock price into domestic currency and then deducting it from the domestic stock price. All the data are retrieved from Datastream.

\section{[Table 1 around here]}

Stationarity in the time series is checked by applying the Augmented Dickey Fuller (ADF) test, see Table 1. The results suggest that it fails to reject the null of a unit root in the logarithm of stock price differentials and the real exchange rate, but overwhelmingly reject the null for the first difference of the series. The two variables are, therefore, differenced series for the GARCH model.

\section{Estimation results}

\section{[Table 2 around here]}

Table 2 is the estimated result from the bivariate DCC-GARCH model. The model is estimated using the quasi-maximum likelihood method to generate consistent standard errors that are robust to non-normality. A closer inspection of the estimated parameters shows that the ARCH parameters, indicated by $\alpha$, are all significant above 1 percent level for both return differentials and real exchange rates for all of the markets except for Canada. In this respect, the null hypothesis of the absence of $\mathrm{ARCH}$ components is rejected, and this indicates the variance of the current error term or innovation to be a function of the squares of the previous time periods' error terms. Furthermore, the coefficients for the lagged conditional volatility, as shown by $\beta$, are significant for all six emerging market and Canada and UK, suggesting a 
high persistence in shocks to the conditional volatility. Note also that, given the larger magnitude of coefficients in $\Delta \rho$, the persistence in volatility is higher for the stock price differentials than that for the real exchange rate for most of the Asian emerging markets.

In addition to the high conditional volatility, the most notable point in our results is the significant time-varying correlation. This effect is captured by the coefficients of $q_{a}$ and $q_{b}$, which are the parameters governing the GARCH process of the Q sequence as in equation (15). Both are mostly highly significant at above 1 percent level, and the conditional correlation exhibits high persistence for all cases over the sample period.

The diagnostic test is reported in the last panel, where the Ljung-Box Qstatistics for up to the $4^{\text {th }}$ orders in the levels and squares of the residuals are reported. It clearly shows that joint linear and non-linear serial correlations in the standardized residual have been eradicated for both the stock return differentials and changes in real exchange rates.

\section{[Figure 1 around here]}

Figure 1 shows the evolution of the conditional correlations of ten countries. In all cases, the plot shows that the DCC falls within the range of 0 to -1 , exhibiting a negative relationship between stock return differentials and real exchange rates throughout the sample period and this is consistent with the model prediction.

In general, quite a volatile movement is evident in the Asian countries, and there are varying trends apparent with the Asian financial crisis period around 199798 as a turning point. These emerging counties experienced stock market liberalisation from the mid to the end of the 1980s. Liberalisation can take many forms, e.g. relaxing currency restrictions, reducing foreign ownership restrictions, or 
allowing capital and dividend repatriation at various points in time. This should have stimulated the integration of local markets with the global market, potentially narrowing the stock market return differentials. An upward movement of DCC in the 1980, except for Malaysia, appears to reflect such experience during financial liberalisation.

These Asian countries were heavily hit by the financial crisis of 1997. During this crisis period, a sudden dislocation of asset demands, or the shift of portfolios from domestic to overseas assets, occurred owing to the herding behaviour of investors or to the loss of confidence in the economy. This resulted in a decrease in the demand for domestic money and a deprecation of the currency ${ }^{8}$. This financial crisis characterised the continuous devaluation of their domestic currencies (their currencies fell on average by around $50 \%$ or more against the dollar) as well as a stock market crash, explaining the sharp fall in the correlation. This is reflected with DCC approaching almost perfect negative correlation. Note that these countries were, in effect, in soft peg regimes for a long time prior to the 1997 events, hence, an abrupt change in the correlation structure after the crisis may be, in part, due to a shift to a free floating regime, (though subsequently, in many cases, soft pegging was resumed or managed floating system was adopted in order to stabilize the exchange rate).

In the post Asian crisis period, the level of pre-crisis correlation was reestablished. This is indicative of some recovery in the financial and economic

\footnotetext{
${ }^{8}$ A crucial role in the Asian crisis was played by financial intermediaries, which were able to raise money at low rates of interest and lend it at higher rates to finance risky investments. This drove up the prices of risky assets. With the bursting of the bubble, prices went into a downward spiral, in which risky asset prices plummeted, causing the insolvency of financial intermediaries, which further contributed to fast price deflation. Besides, heavy reliance on capital inflows as a main source of high levels of domestic credit rendered the Asian market vulnerable. It was seen that massive outflows of portfolio assets and credit gave rise to the collapse of the domestic currency.
} 
conditions in these Asian countries ${ }^{9}$, though for Indonesia, the pre-crisis level of DCC has not fully recovered, where the crisis is said to be the greatest and most prolonged. On the other hand, it is noteworthy that there is a lesser degree of a fall in the correlation during the Asian crisis in Singapore. It is argued that Singapore has weathered the crisis better than most Asian economies, where the managed exchange rate system allowed it to quickly depreciate the Singapore dollar in response to the loss of its export competitiveness arising from the collapse of the regional currencies.

Overall, these results are in agreement with other empirical literature, where the intermarket relationship intensified for a brief period around the crisis, but then quickly resumed their normal pre-crisis period relationship (e.g. Phylaktis and Ravazzolo 2005).

As compared with the emerging markets, the DCC in the developed markets is less volatile and shows less fluctuation. As for Canada and the UK, it is striking that the pattern of the DCC is remarkably similar to each other. In the earlier period of the floating regime the DCC demonstrates an upward movement, i.e. an increase of correlation, which seems to reflect a sharp rise in inflation, hence real appreciation with a falling stock market during the oil crisis period. With its peak in the early 1980s, it started exhibiting a gradual decline in correlation, i.e. the extent of negative correlation has increased, which is associated with the gradual depreciation of their currencies since the 1980s for both countries. Distinguished from Canada and UK, Australia and Japan have shown little trend, since both correlations fluctuate around 0.4 to -0.5 , indicating relatively a stable relationship of the two markets throughout the sample period.

\footnotetext{
${ }^{9}$ For example, foreign funds were returned to these countries.
} 


\section{Analyzing the sources of the dynamic linkage}

\section{Linear model specification}

Having found a significant time-varying correlation between the stock return differentials and changes in real exchange rates, we investigate the potential driving factors behind the linkage. We consider two main strands of the driving forces, economic integration and financial integration, as a channel for the correlation. The former is associated with international competitiveness in the real sector, where depreciation or appreciation of exchange rates affects aggregate domestic demand for goods, so domestic firms' market values may be affected. This, in turn, affects stock prices of firms. We consider the current account surplus/deficit as a proxy to measure the extent of economic integration through international trade as a contributory factor to the correlation. Financial integration is associated with international portfolio behaviour via changes in interest rates causing changes in exchange rates, e.g. international investors are attracted to investing countries, which offer higher stock returns, and this pushes up the value of the currency with the intermediation of the change in interest rates. Thus, interest rate differentials are specified as a proxy to investigate the extent of the role of international capital mobility and, thereby, capital market integration in determining the relationship between stock returns and exchange rates. $^{10}$

In addition to these variables, we introduce country specific control variables by considering their financial development, which is likely to impact on the conditional correlation, independently from those two driving sources. We include a

\footnotetext{
${ }^{10} \mathrm{We}$, initially, intended to use the capital account as a regressor, yet, due to a lack of data availability for the Asian countries in the earlier sample period, interest rates were used. Note that Smith (1992) attempts to examine the relationship between stock markets and exchange rates with the current account position, by specifying exchange rates as dependent variables and the stock prices, current account surplus and the interest rate differentials as independent variables.
} 
stock market development variable that is captured by the market capitalisation relative to GDP, which might alter stock market returns. We also specify the variables of M3 and credit to the private sector, both a percentage of GDP, which are commonly used to measure the extent of financial development. The linear equation takes the following form:

$$
D C C_{i, t}=\beta_{0 i}+\beta_{1 i} D C C_{i t-1}+\beta_{2 i} \Delta(c a s / g d p)_{i t}+\beta_{3 i} \Delta\left(r-r^{*}\right)_{i t}+\beta_{4 i} \Delta F D_{t}+u_{i t}
$$

The dependent variable $D C C$ is the time-varying conditional correlation series for each country $i$, estimated from the previous section $5 .(c a s / g d p)$ is the ratio of the current account to GDP, and $\left(r-r^{*}\right)$ is the real interest rate differential between the domestic country and the US, where the lending rate and the inflation rate, measured by the consumer price index, are used ${ }^{11}$. FD is the sum of the ratio of stock market capitalization to GDP, the ratio of M3 to GDP and the ratio of credit to the private sector to GDP. All data are retrieved from Datastream. Since monthly data for the current account are not available, all data are quarterly observations. DCC was converted from monthly to quarterly time series. Quarterly data are, after all, more plausible than monthly data in terms of measuring the impact of the current account on DCC, since the response to the real sector is likely to take longer than a month ${ }^{12}$.

\footnotetext{
${ }^{11}$ Mortgage rates are used for lending rates. This is based on data availability; mortgage rates are consistently found for the whole sample period for these Asian countries, whereas there is a lack of data availability for lending rates for the earlier sample period, e.g. Indonesia starts with 2000, or the lending rates are not available for some Asian countries. Note also that for some countries, mortgage rates are treated as lending rates under the code ' $60 \mathrm{P} . . \mathrm{ZF}$ ', in International Financial Statistics.

12 However, we acknowledge that an analysis on monthly data may provide different results, in particular for financial integration, where the dynamic movement is much faster than that of real sector. This can be explored by conducting a further research on other countries where data are available.
} 
Unit root tests for the variables are conducted with the ADF test, and all variables are found to be nonstationary, at least at the 5 percent significance level. Therefore all the variables are in first difference, as indicated by $\Delta$ in equation (17).

Since, there is potentially an endogeneity problem among dependent and independent variables, the instrument variable (IV) method is adopted. The instrument variables, which are orthogonal to the disturbances, are the lagged once and twice explanatory variables in levels together with the lagged dependent variable.

We, preliminarily, examined the impact of the Asian crisis on the dynamic correlation by regressing DCC on a dummy variable, i.e. dummy one for the 1997:4 onwards and zero otherwise for the Asian markets. We mostly found a significant coefficient on the dummy. Hence, we separately estimate the model for the post financial crisis period for the Asian countries.

\section{Linear estimation results}

The results of the linear regression for the whole sample period are shown in Table 3a, and those for the post-crisis period are in Table 3b. Diagnostic test results indicate that in many cases the Breusch-Godfrey serial correlation test indicates the absence of serial correlation at the 5 percent level. The residuals tend to reject the null of homoskedasticity, hence the regression is corrected using robust estimation with White's heteroskedastic consistent t-ratios. The over-identification tests suggest that the null is not rejected in all cases at the 1 percent level. On balance, these diagnostic tests are quite satisfactory to warrant drawing inferences from the results. For discussion, we, first, concentrate on the estimates of the whole sample periods in Table $3 \mathrm{a}$, then those of the subsample period in Table $3 \mathrm{~b}$ at the end of this section.

\section{[Table 3 around here]}


The lagged dependent variable has been shown to be statistically highly significant in all cases, indicating strong persistence in the dynamic correlation.

In Table 3a, apart from Singapore these emerging Asian countries have the significant coefficient of cas/gdp, suggesting that the dynamic linkage between stock and foreign exchange markets is closely associated with the trade balance. The signs on the coefficients are negative, except for Malaysia, implying that the advance of the current account is associated with a negative correlation. It can be explained in that the improvement of the current account gives a boost to share prices, and also increases the value of the domestic currency. Hence, when an economy enjoys the current account surplus, a negative correlation can be enhanced. However, if a lower value of currency generates price competitiveness, the trade balance improves, hence the real output of a country, which in turn affects current and future cash flows of firms, and their stock prices can be boosted. If this effect is strong, we may observe a positive sign on the coefficient of cas/gdp: a positive correlation in $\rho_{t}$ and $q_{t}$ is the consequence, as in the case of Malaysia ${ }^{13}$.

The result is indicative of the role of the real sector as a conduit of the correlation, and this appears to reflect their trade-led association with the US markets in favouring the 'flow-oriented' models of exchange rates (Dornbusch and Fischer 1980).

On the other hand, the coefficients on the interest rate differentials are not well-determined for the Asian markets in Table 3a, as we find significant coefficients only at the 10 percent level for Indonesia, Korea and Philippine and not significant for other Asian countries. Also, note that there is little effect of financial development $(\triangle F D)$ on the correlation. This suggests that the correlation is less robust through the

\footnotetext{
${ }^{13}$ Whether it has a positive or negative sign on the trade balance depends on the direction of causality between stock and exchange markets.
} 
financial integration. The result seems to reflect restricted capital mobility typically found in emerging markets. We also note that Thailand and the Philippines maintained restrictions on foreign exchange movements and foreign ownership even after they opened their markets to foreign investors ${ }^{14}$.

We seem to have a different picture for the developed countries from that for emerging economies. For Canada, given the fact that the coefficients on both $c a s / g d p$ and $r-r^{*}$ are statistically significant at the 5 percent level, the results reflect the substantial link with the US market through both international trade and capital mobility in determining the conditional correlations. In the case of the UK and Australia, whereas the coefficient on the current account is not significant, that of the interest rate differentials is significant at the 5 percent level. This reveals the sensitivity of the time-varying correlation to interest rate differentials. The result suggests a high degree of capital mobility amongst the developed markets.

The magnitudes of the coefficient on $r-r^{*}$ between Canada and the UK are not different from each other at 0.0039 and 0.0025 respectively, whereas Australia has shown a relatively large size of 0.0067 . A negative sign indicates that a rise in the relative interest rate leads to a further negative correlation, and this is supportive to the portfolio approach to exchange rate determination, where the equities, being part of wealth, may affect the behaviour of exchange rates through the demand for money, hence interest rates (Branson 1983, Frankel 1983 and Phylaktis and Ravazzolo, 2005). This result may imply that financial integration as a channel of correlation may be overriding that of the economic integration in these two developed economies. In the

\footnotetext{
${ }^{14}$ The results for Thailand and the Philippines are inconsistent with that of Phylaktis and Ravazzola (2005), who found that the stock and exchange markets are connected more through financial sector integration, rather than through the real sector during the period 1980-1998. However, their test lacks rigour, as it was conducted by the Granger-causality technique without explicitly specifying important variables such as the current account, nor the interest rate differentials.
} 
case of Japan, where significant coefficients are observed neither on the current account balance, nor on the interest rate differentials. Yet, likewise UK, it has a highly significant coefficient on $\Delta F D_{t}$, and that the linkage of the stock and foreign exchange markets is sensitive to the development of financial markets, leaning to the financial sector channel of the correlation.

In the post Asian crisis period in Table $3 b$, there emerges some shift in the driving force of the correlation for these emerging markets. It is evidenced that a number of significant coefficient on $\Delta\left(r-r^{*}\right)_{t}$ has increased, by contrast that of $\Delta(\text { cas } / g d p)_{t}$ has decreased. This implies that the correlation has become more determined by forces in financial sector than before. In particular, Indonesia and Philippine have witnessed a shift from economic to financial integration as a major driving factor of the correlation. South Korea and Malaysia are more or less remains to be the same ${ }^{15}$, whereas Thailand has shown a valid role of financial integration as a source of the correlation after the crisis. The shift observed for some Asian markets may reflect the increased degree of capital mobility in the post financial crisis period.

Note that in the case of Singapore, financial markets started developing at a much earlier stage than in other Asian markets, with more capital mobility and flexible exchange rate regimes. In Table $3 \mathrm{a}$ for the whole sample period, we find no significant coefficients among these variables, yet in the post Asian crisis period, the coefficient on $\Delta\left(r-r^{*}\right)_{t}$ becomes significant at the $10 \%$ level. Hence, although we are unable to draw a similar inference for Singapore as for other Asian economies, the significant coefficient on the interest rate differentials after the crisis appears to indicate the role of financial integration as the main source of the correlation.

\footnotetext{
${ }^{15}$ In the period leading up to the Asian crisis, Malaysia had inflexible exchange rates. With brief spells of flexibility during the Asian financial crisis, the Malaysian Ringgit had gone back towards inflexibility after the crisis subsided (Patnaik et al 2010).
} 
In the case of developed countries, we found that there are little shifts in the post crisis period, since the significant coefficients in Table $3 \mathrm{~b}$ are broadly similar to those of the whole sample period in Table 3a. It appears that the Asian crisis may have changed the shape of the determinants of DCC between stock returns and foreign exchange rates for these Asian countries, but not for these developed countries.

\section{Conclusion}

In this paper, we have examined the determinants of the time-varying correlation between stock return differentials and real exchange rates for the six Asian emerging markets and the four developed markets. The results from the empirical analysis have highlighted a number of interesting issues.

Firstly, the finding of significant time-varying correlation between the two time series implies that the DCC approach may be an appropriate approximation for investigating the relationship. Also, it suggests that the US stock market influences these economies by bringing together the foreign exchange and the local stock markets. Secondly, the evidence of the negative relationship between the stock and foreign exchange markets seems to support the theoretical model prediction with the assumption of temporary and permanent components of stock return differentials and real exchange rates. Thirdly, the driving force of the dynamic link of the two series is, in general, associated with the current account balance for the Asian countries, suggesting the leading role of economic integration with the US. An increase in trade balance binds the ties between stock and foreign exchange markets for these economies. The weak interest rate channel, as a source of the dynamic link, seems to indicate, as yet, restrictive financial markets in some emerging economies. Yet, a further empirical analysis reveals the increased capital mobility for some Asian markets in the aftermath of the Asian crisis. For Canada, the linkage can be fostered through the channels of both international trade and capital mobility, whilst the 
correlation is emphasised via interest rate differentials for the Australia and UK. The high degree of capital market integration with the US market provides a possible explanation for the latter result, and it stresses the sensitivity of well-developed financial markets to changes in interest rates. This should have implications for policymakers in interest-rate setting.

On balance, our empirical results suggest whether the stock oriented model or the flow-oriented model is supported or not may depends on the degree of maturity in financial markets. The investigation of the sources of the dynamic correlation can be extended, for example, by augmenting the linear model with other potential variables, which might affect the linkage, and also by applying it to other countries, which may help to confirm our contrasting findings between developed and emerging countries.

\section{References}

Abdalla, I. and Murinde, V. (1997). Exchange rate and stock price interactions in emerging financial markets: evidence of India, Korea, Pakistan and the Philippines, Applied Financial Economics, 7, 25-35.

Ajayi, R.A., Friedman, J. and Mehdian, S.M. (1998) On the relationship between stock returns and exchange rates: tests of Granger causality, Global finance Journal, 9, 241-251.

Bahmani-Oskooee, M. and Sohrabian, A. (1992) Stock prices and the effective exchange rate of the dollar, Applied Economics, 24(4), 459-464.

Bautista, C.C. (2006). The exchange rate-interest differential relationship in six East Asian countries, Economics Letters, 96, 137-142

Baxter, M. (1994). Real exchange rates and real interest differentials. Have we missed the business-cycle relationship? Journal of Monetary Economics, 33, 5-37.

Branson, W.H., (1983). Macroeconomic determinants of real exchange rate risk. In: Herring, R.J. (Ed.), Managing Foreign Exchange Rate Risk. Cambridge University Press, Cambridge, MA. 
Caporale, G.M. and Pittis, N. (1997). Causality and forecasting in incomplete systems, Journal of Forecasting, 16, 425-437.

Chen B. and Tran K, (1994). Are we sure that the real exchange rate follows a random walk? A re-examination, International Economic Journal, 33-44.

Chiang, T. C., B.N. Jeon and H. Li (2007). Dynamic correlation analysis of financial contagion: Evidence from Asian markets, Journal of International Money and Finance, 26, 1206-1228.

Dornbusch, R., S. Fisher, (1980). Exchange rates and the current account. American Economic Review 70, 960-971.

Engle, R. (2002). Dynamic conditional correlation: A simple class of multivariate generalized autoregressive conditional Heteroskedasticity models. Journal of Business and Economic Statistics 20, 339-350.

Fama, F. and French, K.R. (1988). Testing the predictive power of dividend yields, Journal of Finance, 48, 663-679.

Frankel, J.A., (1983). Monetary and portfolio balance models of exchange rate determination. In: Bhandari, J.S., Putnam, B.H. (Eds.), Economic Interdependence and Flexible Exchange Rates. MIT Press, Cambridge, MA.

Forbes, K.J and R. Rigobon (2002). No Contagion, Only Interdependence: Measuring Stock Market Comovements, The Journal of Finance, Vol. 57, No. 5, pp. 2223-2261.

Granger, C.W.J., Huang, B.N. and Yang, C.W. (2000) A bivariate causality between stock prices and exchange rates: evidence from recent Asian flu, Quarterly review of Economics and Finance, 40, 337-354.

Hatemi-J, A and M. Irandoust (2002). On the causality between exchange rates and stock prices: A note, Bulletin of Economic Research 54, 197-203.

Huizinga, J. (1987). An empirical investigation of the long-run behaviour of real exchange rates, Carnegie-Rochester Conference Series Public Policy, 27, 149214.

Kanas, A. (2000). Volatility spillovers between stock returns and exchange rate changes: International evidence. Journal of Business and Accounting, 27, 447-467.

Loudon, G. (1993). The foreign exchange operating exposure of Australian stocks, Accounting and Finance, 33, 19-32.

Ma, C.K. and Kao, G.W. (1990). On exchange rate changes and stock price reactions, Journal of Business Finance and Accounting, 17, 441-449.

Malliaropulos, D. (1998). International stock return differentials and real exchange rate changes, 17, Journal of International Money and finance, 493-511. 
Moore, T. (2007a). The Effects of the Euro on Stock markets: Evidence from Hungary, Poland and UK, Journal of Economic Integration, 22(1) March, 6990.

Moore, T. (2007b). Has entry to the European Union altered the dynamic links of stock returns for the emerging markets? Applied Financial Economics, 17, 1431-1446.

Nieh, C.C. and Lee, C.F. (2001) Dynamic relationship between stock prices and exchange rates for G7 countries, Quarterly Review of Economics and Finance, 41, 477-490.

Pan, M.S. Chi-Wing Fok,R. and Angela Liu, Y. (2007). Dynamic linkages between exchange rates and stock prices: Evidence from East Asian markets. International Review of Economics \& Finance, 16(4), 503-520.

Patnaik, I. Shah, A. Sethy, A. and Balasubramaniam, V. (2010). The exchange rate regime in Asia: From crisis to crisis, International Review of Economics and Finance, forthcoming.

Phylaktis, K. and Ravazzolo, F (2005). Stock prices and exchange rate dynamics, Journal of International Money and Finance, 24, 1031-1053.

Poterba, J.M. and Summers, L.H. (1988). Mean reversion in stock prices: Evidence and implications, Journal of Financial Economics, 22, 27-59.

Smith, C. (1992). Stock markets and the exchange rate: a multicountry approach, Journal of Macroeconomics 14, 607-629.

Smyth, R. and Nandha, M. (2003). Bivariate causality between exchange rates and stock prices in South Asia, Applied Economics Letters, 10, 699-704.

Soenen L. and Hennigar E. (1988). An analysis of exchange rates and stock prices the US experience between 1980 and 1986, Akron Business and Economic Review, 19, 7-16.

Wang, P. and Moore, T. (2008). Financial Market Integration for the transition economies: time-varying conditional correlation approach, The Manchester School, 76(1) September, 116-133. 
Table 1 Unit root tests

\begin{tabular}{lcccc}
\hline & $\rho$ & $q$ & $\Delta \rho$ & $\Delta q$ \\
\hline Indonesia & -1.407 & -1.999 & -15.033 & -14.167 \\
Korea & -1.540 & -2.182 & -15.512 & -18.854 \\
Malaysia & -1.480 & -0.627 & -10.027 & -19.090 \\
Philippine & -1.136 & -1.565 & -13.395 & -20.694 \\
Singapore & -2.161 & -2.775 & -18.122 & -19.313 \\
Thailand & -0.974 & -1.437 & -16.976 & -17.537 \\
Australia & -0.230 & -2.136 & -19.179 & -15.047 \\
Canada & -1.051 & -1.555 & -20.567 & -20.104 \\
Japan & -0.701 & -2.336 & -19.813 & -18.693 \\
UK & -2.318 & -2.074 & -18.973 & -18.981 \\
\hline
\end{tabular}

Note: $\rho_{t}=s_{t}-s_{t}^{*}-e_{t}$ : the stock price differential. $q_{t}=e_{t}+p_{t}^{*}-p_{t}:$ the real exchange rate. ADF unit root test. Lag length is based on the Schwarz Information Criterion. Critical values are -3.44, -2.87 and -2.57 at $1 \%, 5 \%$ and $10 \%$ levels, respectively. 
Table 2 Estimates from the bivariate DCC-GARCH model

\begin{tabular}{|c|c|c|c|c|c|c|c|c|c|c|}
\hline & Indonesia & Korea & Malaysia & Philippine & Singapore & Thailand & Australia & Canada & Japan & UK \\
\hline \multicolumn{11}{|c|}{$\Delta \rho$ (Stock return differential) } \\
\hline$\mu$ & $\begin{array}{l}-0.5339 \\
(0.5461) \\
\end{array}$ & $\begin{array}{l}0.3247 \\
(0.3926)\end{array}$ & $\begin{array}{l}-0.1144 \\
(0.3312) \\
\end{array}$ & $\begin{array}{l}0.1095 \\
(0.5658) \\
\end{array}$ & $\begin{array}{l}0.0106 \\
(0.2534)\end{array}$ & $\begin{array}{l}-0.3315 \\
(0.4115) \\
\end{array}$ & $\begin{array}{l}-0.2181 \\
(0.2938)\end{array}$ & $\begin{array}{l}-0.2422 \\
(0.1717) \\
\end{array}$ & $\begin{array}{l}-0.1897 \\
(0.2814)\end{array}$ & $\begin{array}{l}0.0262 \\
(0.2087)\end{array}$ \\
\hline$\omega$ & $\begin{array}{l}7.8832 * * \\
(3.4567) \\
\end{array}$ & $\begin{array}{l}7.4380 * * \\
(3.3566) \\
\end{array}$ & $\begin{array}{l}2.8121 * * \\
(1.2233) \\
\end{array}$ & $\begin{array}{l}4.9505 \\
(3.9099) \\
\end{array}$ & $\begin{array}{l}2.3692 * * * \\
(0.9085)\end{array}$ & $\begin{array}{l}3.6226 \\
(2.4515) \\
\end{array}$ & $\begin{array}{l}23.4960 * * * \\
(6.1690)\end{array}$ & $\begin{array}{l}2.0134 \\
(2.3409) \\
\end{array}$ & $\begin{array}{l}25.5727 * * * \\
(7.2942)\end{array}$ & $\begin{array}{l}0.7486 \\
(0.4763) \\
\end{array}$ \\
\hline$\alpha$ & $\begin{array}{l}0.2258 * * * \\
(0.0492)\end{array}$ & $\begin{array}{l}0.2559 * * * \\
(0.0566)\end{array}$ & $\begin{array}{l}0.2339 * * * \\
(0.0588)\end{array}$ & $\begin{array}{l}0.1397 * * * \\
(0.0562)\end{array}$ & $\begin{array}{l}0.2244 * * * \\
(0.0361)\end{array}$ & $\begin{array}{l}0.1360 \text { *** } \\
(0.0408)\end{array}$ & $\begin{array}{l}0.2567 * * * \\
(0.0796)\end{array}$ & $\begin{array}{l}0.0728 \\
(0.0521)\end{array}$ & $\begin{array}{l}0.1942 * * * \\
(0.0550)\end{array}$ & $\begin{array}{l}0.0600 * * \\
(0.0266)\end{array}$ \\
\hline$\beta$ & $\begin{array}{l}0.77838 * * * \\
(0.0401)\end{array}$ & $\begin{array}{l}0.6805 * * * \\
(0.0714)\end{array}$ & $\begin{array}{l}0.7439 * * * \\
(0.0526)\end{array}$ & $\begin{array}{l}0.8193 * * * \\
(0.0735) \\
\end{array}$ & $\begin{array}{l}0.7444 * * * \\
(0.0372)\end{array}$ & $\begin{array}{l}0.8244 * * * \\
(0.0540)\end{array}$ & $\begin{array}{l}0.1051 \\
(0.1719) \\
\end{array}$ & $\begin{array}{l}0.7635 \text { *** } \\
(0.2276) \\
\end{array}$ & $\begin{array}{l}0.1808 \\
(0.1700) \\
\end{array}$ & $\begin{array}{l}0.9031 \text { *** } \\
(0.0405)\end{array}$ \\
\hline \multicolumn{11}{|c|}{$\Delta q$ (Real exchange rate) } \\
\hline$\mu$ & $\begin{array}{l}0.0412 \\
(0.2079) \\
\end{array}$ & $\begin{array}{l}0.0109 \\
(0.0607) \\
\end{array}$ & $\begin{array}{l}0.1468 * * * \\
(0.0558)\end{array}$ & $\begin{array}{l}-0.0815 \\
(0.1157) \\
\end{array}$ & $\begin{array}{l}-0.1704 \\
(0.1121)\end{array}$ & $\begin{array}{l}0.0437 \\
(0.1137) \\
\end{array}$ & $\begin{array}{l}-0.0977 \\
(0.1323) \\
\end{array}$ & $\begin{array}{l}0.1019 \\
(0.0781) \\
\end{array}$ & $\begin{array}{l}0.0203 \\
0.1482 \\
\end{array}$ & $\begin{array}{l}-0.1270 \\
(0.1337) \\
\end{array}$ \\
\hline$\omega$ & $\begin{array}{l}4.7687 * * * \\
(1.0495)\end{array}$ & $\begin{array}{l}0.1645^{* * *} \\
(0.0769)\end{array}$ & $\begin{array}{l}0.1912 * * * \\
(0.0765)\end{array}$ & $\begin{array}{l}0.7294 * * * \\
(0.2031)\end{array}$ & $\begin{array}{l}0.32940 * * * \\
(0.1252)\end{array}$ & $\begin{array}{l}1.7834^{* * *} \\
(0.3828)\end{array}$ & $\begin{array}{l}2.2794 * * * \\
(0.7661)\end{array}$ & $\begin{array}{l}0.1548 \\
(0.1408)\end{array}$ & $\begin{array}{l}8.2210 * * * \\
(1.7519)\end{array}$ & $\begin{array}{l}0.1215 \\
(0.1195)\end{array}$ \\
\hline$\alpha$ & $\begin{array}{l}0.5996 * * * \\
(0.1573) \\
\end{array}$ & $\begin{array}{l}0.5967 * * * \\
(0.1163) \\
\end{array}$ & $\begin{array}{l}0.4560 * * * \\
(0.1031)\end{array}$ & $\begin{array}{l}0.3308 * * * \\
(0.1123) \\
\end{array}$ & $\begin{array}{l}0.0920 * * * \\
(0.0301)\end{array}$ & $\begin{array}{l}0.1699 * * * \\
(0.0540) \\
\end{array}$ & $\begin{array}{l}0.2633 \text { *** } \\
(0.1161) \\
\end{array}$ & $\begin{array}{l}0.05118 \\
(0.0351) \\
\end{array}$ & $\begin{array}{l}0.1864 * * * \\
(0.0672) \\
\end{array}$ & $\begin{array}{l}0.0567 * * * \\
(0.0219)\end{array}$ \\
\hline$\beta$ & $\begin{array}{l}0.4976 * * * \\
(0.0851)\end{array}$ & $\begin{array}{l}0.5476 * * * \\
(0.0692)\end{array}$ & $\begin{array}{l}0.5609 * * * \\
(0.0744)\end{array}$ & $\begin{array}{l}0.5905 * * * \\
(0.0882)\end{array}$ & $\begin{array}{l}0.8602 * * * \\
(0.0350)\end{array}$ & $\begin{array}{l}0.5785 * * * \\
(0.0799)\end{array}$ & $\begin{array}{l}0.3628 * * \\
(0.1700)\end{array}$ & $\begin{array}{l}0.8840 \text { *** } \\
(0.0891)\end{array}$ & $\begin{array}{l}0.0738 \\
(0.1510)\end{array}$ & $\begin{array}{l}0.9315 * * * \\
(0.0282)\end{array}$ \\
\hline \multicolumn{11}{|l|}{ DCC parameters } \\
\hline$q_{a}$ & $\begin{array}{l}0.0832 * * * \\
(0.0326)\end{array}$ & $\begin{array}{l}0.0809 * * * \\
(0.0277)\end{array}$ & $\begin{array}{l}0.0748 \\
(0.0500)\end{array}$ & $\begin{array}{l}0.0728^{*} \\
(0.0404)\end{array}$ & $\begin{array}{l}0.0211 \\
(0.0143)\end{array}$ & $\begin{array}{l}0.0753 * * \\
(0.0386)\end{array}$ & $\begin{array}{l}0.0356 \\
(0.0333)\end{array}$ & $\begin{array}{l}0.0213 * * \\
(0.0101)\end{array}$ & $\begin{array}{l}0.1026 * * * \\
(0.0401)\end{array}$ & $\begin{array}{l}0.0194 * * * \\
(0.0056)\end{array}$ \\
\hline$q_{b}$ & $\begin{array}{l}0.8528 * * * \\
(0.0606)\end{array}$ & $\begin{array}{l}0.9032 * * * \\
(0.0336)\end{array}$ & $\begin{array}{l}0.6248 * * \\
(0.2865)\end{array}$ & $\begin{array}{l}0.8586 \text { *** } \\
(0.0766)\end{array}$ & $\begin{array}{l}0.8339 * * * \\
(0.1601)\end{array}$ & $\begin{array}{l}0.8617 * * * \\
(0.0626)\end{array}$ & $\begin{array}{l}0.7971 \text { **** } \\
(0.1362)\end{array}$ & $\begin{array}{l}0.9684 * * * \\
(0.0201)\end{array}$ & $\begin{array}{l}0.6728 * * * \\
(0.1274)\end{array}$ & $\begin{array}{l}0.9854 * * * \\
(0.0070)\end{array}$ \\
\hline Log likelihood & -1800.29 & -1729.54 & -1599.33 & -1431.14 & -2271.58 & -1922.51 & -2166.59 & -1727.91 & -2304.16 & -2058.12 \\
\hline \multicolumn{11}{|l|}{ Diagnostic test } \\
\hline Stock Q(4) & 2.9193 & 5.4985 & 7.0461 & 6.0258 & 8.5636 & 0.9667 & 1.0445 & 7.2714 & 3.8401 & 3.1472 \\
\hline Stock $\mathrm{Q}(4)^{2}$ & 1.7670 & 4.0687 & 7.1109 & 3.9717 & 3.3885 & 1.8921 & 2.8900 & 0.5042 & 3.7567 & 9.6383 \\
\hline Exchange rate Q(4) & 3.3589 & 4.5059 & 15.0080 & 3.6942 & 5.8097 & 4.9681 & 30.0394 & 0.4368 & 9.553 & 0.4521 \\
\hline Exchange rate $\mathrm{Q}(4)^{2}$ & 0.0459 & 7.2435 & 2.2497 & 0.5410 & 0.6285 & 0.0769 & 1.0009 & 0.8787 & 2.6691 & 2.7675 \\
\hline
\end{tabular}

Note: Standard errors are in parenthesis. *,** and ***: significant at the $10 \%, 5 \%$ and $1 \%$ level respectively. Q(4) and $\mathrm{Q}^{2}(4)$ are the Ljung-Box Q-statistic for the $4^{\text {th }}$ orders in the levels and squares of the residuals, respectively. Under the hypothesis of no serial correlation, the critical value is 9.49 at the $5 \%$ level. 
Table 3a Instrument variable estimates for the whole sample period: dependent $D C C_{t}$

\begin{tabular}{|l|l|l|l|l|l|l|}
\hline All sample & Indonesia & Korea & Malaysia & Philippine & Singapore & Thailand \\
\hline Constant & $-0.0875 * * *$ & $-0.0867 * * *$ & $-0.1233 * * *$ & $-0.0364 *$ & $-0.0575 * * *$ & $-0.0478 *$ \\
& $(0.0225)$ & $(0.0207)$ & $(0.0336)$ & $(0.0193)$ & $(0.0150)$ & $(0.0271)$ \\
\hline$D C C_{t-1}$ & $0.90658 * * *$ & $0.9069 * * *$ & $0.5776^{* * *}$ & $0.9119 * * *$ & $0.6533 * * *$ & $0.8928 * * *$ \\
& $(0.0270)$ & $(0.0338)$ & $(0.1110)$ & $(0.0466)$ & $(0.0921)$ & $(0.0637)$ \\
\hline$\Delta($ cas $/ g d p$ & $-0.000503 * *$ & $-0.000504 * *$ & $0.2484 * *$ & $-0.00049 * * *$ & 0.0001 & $-0.00045 * *$ \\
)$_{t}$ & $(0.0002)$ & $(0.0002)$ & $(0.1206)$ & $(0.0002)$ & $(0.0225)$ & $(0.0002)$ \\
\hline$\Delta\left(r-r^{*}\right)_{t}$ & $0.0022 *$ & $0.0021 *$ & 0.0121 & $-0.0074 *$ & -0.0029 & 0.0043 \\
& $(0.0013)$ & $(0.0012)$ & $(0.0084)$ & $(0.0040)$ & $(0.0021)$ & $(0.0090)$ \\
\hline$\Delta F D_{t}$ & 0.0068 & 0.00002 & $0.4310 *$ & -0.0161 & 0.0323 & 0.0322 \\
& $(0.0170)$ & $(0.00004)$ & $(0.2228)$ & $(0.0231)$ & $(0.0306)$ & $(0.0429)$ \\
\hline Serial $(1)$ & {$[0.7096]$} & {$[0.7228]$} & {$[0.9343]$} & {$[0.0391]$} & {$[0.9515]$} & {$[0.0172]$} \\
\hline Serial $(2)$ & {$[0.9042]$} & {$[0.8865]$} & {$[0.7834]$} & {$[0.1251]$} & {$[0.9906]$} & {$[0.0355]$} \\
\hline Hetero & {$[0.0096]$} & {$[0.0054]$} & {$[0.0394]$} & {$[0.0545]$} & {$[0.7140]$} & {$[0.0461]$} \\
\hline Over id. & {$[0.0962]$} & {$[0.2334]$} & {$[0.5344]$} & {$[0.2166]$} & {$[0.8756]$} & {$[0.0364]$} \\
\hline
\end{tabular}

\begin{tabular}{|l|l|l|l|l|}
\hline All sample & Australia & Japan & Canada & UK \\
\hline Constant & $-0.1196 * * *$ & $-0.2245^{* * *}$ & $-0.0148^{* *}$ & $0.0226^{*}$ \\
& $(0.0249)$ & $(0.0398)$ & $(0.0058)$ & $(0.0121)$ \\
\hline$D C C_{t-1}$ & $0.7003 * * *$ & $0.5544 * * *$ & $0.9333 * * *$ & $0.9063 * * *$ \\
& $(0.0620)$ & $(0.0769)$ & $(0.0267)$ & $(0.0303)$ \\
\hline$\Delta(c a s / g d$ & 0.0013 & -1.3107 & $-0.0011 * * *$ & -0.1211 \\
$p)_{t}$ & $(0.0016)$ & $(7.2291)$ & $(0.0004)$ & $(0.1259)$ \\
\hline$\Delta\left(r-r^{*}\right)_{t}$ & $-0.0067 * *$ & -0.0063 & $-0.0039 * *$ & $-0.0025 * * *$ \\
& $(0.0022)$ & $(0.0055)$ & $(0.0016)$ & $(0.0009)$ \\
\hline$\Delta F D_{t}$ & -0.0082 & $-0.1459 * * *$ & $-0.00003 *$ & $-0.0081 * * *$ \\
& $(0.0237)$ & $(0.0549)$ & $(0.00002)$ & $(0.0026)$ \\
\hline Serial $(1)$ & {$[0.1279]$} & {$[0.2846]$} & {$[0.7033]$} & {$[0.1259]$} \\
\hline Serial $(2)$ & {$[0.2151]$} & {$[0.3060]$} & {$[0.3558]$} & {$[0.3187]$} \\
\hline Hetero & {$[0.0009]$} & {$[0.0021]$} & {$[0.2398]$} & {$[0.0031]$} \\
\hline Over id. & {$[0.2534]$} & {$[0.7780]$} & {$[0.1509]$} & {$[0.0442]$} \\
\hline
\end{tabular}

Table $3 \mathrm{~b}$ Instrument variable estimates for the post crisis period: dependent $D C C_{t}$

\begin{tabular}{|l|l|l|l|l|l|l|}
\hline Subsample & Indonesia & Korea & Malaysia & Philippine & Singapore & Thailand \\
\hline Constant & 0.0821 & $-0.6152^{*}$ & $-0.2819^{* * *}$ & -0.0060 & $-0.0713^{* * *}$ & $-0.0836^{* *}$ \\
& $(0.0869)$ & $(0.3619)$ & $(0.0552)$ & $(0.0331)$ & $(0.0264)$ & $(0.0372)$ \\
\hline$D C C_{t-1}$ & $0.8733^{* * *}$ & $0.8753 * * *$ & $0.4862^{* * *}$ & $0.8874 * *$ & $0.5379 * * *$ & $0.7976^{* * *}$ \\
& $(0.0832)$ & $(0.1069)$ & $(0.1247)$ & $(0.0649)$ & $(0.1659)$ & $(0.0792)$ \\
\hline$\Delta($ cas $/ g d$ & -0.00030 & $-0.00095^{*}$ & $1.2795^{* * *}$ & 0.00018 & -0.0357 & $-0.00040^{*}$ \\
$p)_{t}$ & $(0.00029)$ & $(0.00057)$ & $(0.3148)$ & $(0.00026)$ & $(0.0513)$ & $(0.00023)$ \\
\hline$\Delta\left(r-r^{*}\right)_{t}$ & $0.0027 * *$ & $0.0172^{*}$ & 0.0106 & $-0.0094 * *$ & $-0.0044 *$ & $-0.0121 * *$ \\
& $(0.0013)$ & $(0.0090)$ & $(0.0098)$ & $(0.0043)$ & $(0.0027)$ & $(0.0055)$ \\
\hline$\Delta F D_{t}$ & $-0.0281 * *$ & $0.0550 *$ & 0.1258 & $0.0541 * *$ & 0.0155 & 0.0263 \\
& $(0.0123)$ & $(0.0345)$ & $(0.2929)$ & $(0.0276)$ & $(0.0391)$ & $(0.0449)$ \\
\hline Serial $(1)$ & {$[0.3292]$} & {$[0.8919]$} & {$[0.3162]$} & {$[0.6866]$} & {$[0.6987]$} & {$[0.0861]$} \\
\hline Serial $(2)$ & {$[0.6187]$} & {$[0.0845]$} & {$[0.4993]$} & {$[0.4126]$} & {$[0.9146]$} & {$[0.2293]$} \\
\hline Hetero & {$[0.1464]$} & {$[0.4927]$} & {$[0.0777]$} & {$[0.0704]$} & {$[0.0017]$} & {$[0.0306]$} \\
\hline Over id. & {$[0.6239]$} & {$[0.2852]$} & {$[0.3287]$} & {$[0.3879]$} & {$[0.8193]$} & {$[0.1189]$} \\
\hline
\end{tabular}




\begin{tabular}{|l|l|l|l|l|}
\hline $\begin{array}{l}\text { Sub } \\
\text { sample }\end{array}$ & Australia & Japan & Canada & UK \\
\hline Constant & $-0.1245^{* * *}$ & $-0.2464 * * *$ & $0.0001 * *$ & $0.1180^{* *}$ \\
& $(0.0451)$ & $(0.0727)$ & $(0.00004)$ & $(0.0787)$ \\
\hline DCC $_{t-1}$ & 0.7073 & $0.5137 * * *$ & $0.9723 * * *$ & $0.8248^{* * *}$ \\
& $(0.1108)^{* * *}$ & $(0.1422)$ & $(0.3252)$ & $(0.2946)$ \\
\hline$\Delta($ cas $/ g d$ & 0.0016 & -1.9107 & $-0.0011^{* * *}$ & -0.2041 \\
$p)_{t}$ & $(0.0031)$ & $(-3.9197)$ & $(-0.0003)$ & $(-0.1701)$ \\
\hline$\Delta\left(r-r^{*}\right)_{t}$ & $-0.0060^{* *}$ & $-0.0202^{*}$ & $-0.0057 * * *$ & $-0.0039 * * *$ \\
& $(-0.0030)$ & $(0.0106)$ & $(-0.0014)$ & $(-0.0013)$ \\
\hline$\Delta F D_{t}$ & -0.0100 & $-0.1231 * * *$ & $-0.00010 * *$ & $-0.0265^{* *}$ \\
& $(-0.0175)$ & $(-0.0492)$ & $(-0.00005)$ & $(-0.0133)$ \\
\hline Serial $(1)$ & {$[0.0016]$} & {$[0.4974]$} & {$[0.8462]$} & {$[0.2379]$} \\
\hline Serial $(2)$ & {$[0.0068]$} & {$[0.7819]$} & {$[0.7925]$} & {$[0.0988]$} \\
\hline Hetero & {$[0.3398]$} & {$[0.3431]$} & {$[0.5914]$} & {$[0.2061]$} \\
\hline Over id. & {$[0.3598]$} & {$[0.0650]$} & {$[0.4349]$} & {$[0.0170]$} \\
\hline
\end{tabular}

Notes for Table 3a and 3b: The whole sample period in Table 3a is from 1970s and 1980s to 2006:4. The sub-sample period in Table 3b is from 1997:4 to 2006:4. White's heteroskedastic consistent standard errors are in parenthesis. *, ** and ***: Significant at the $10 \%, 5 \%$ and $1 \%$ level. Instrument variables used are Constant, $D C C_{t-1}, D C C_{t-2},(c a s / g d p)_{t-1,},\left(r-r^{*}\right)_{t-1,}, F D_{t-1,},(c a s / g d p)_{t-2},\left(r-r^{*}\right)_{t-2}$ and $F D_{t-2}$. [ . ] p-values for Breusch-Godfrey serial correlation test, Breusch-Pagan-Godfrey hetroskedasticity test and over identification. 
Figure 1 Time-varying correlations between stock return differentials and real exchange rates

a) Emerging Asian markets

Indonesia

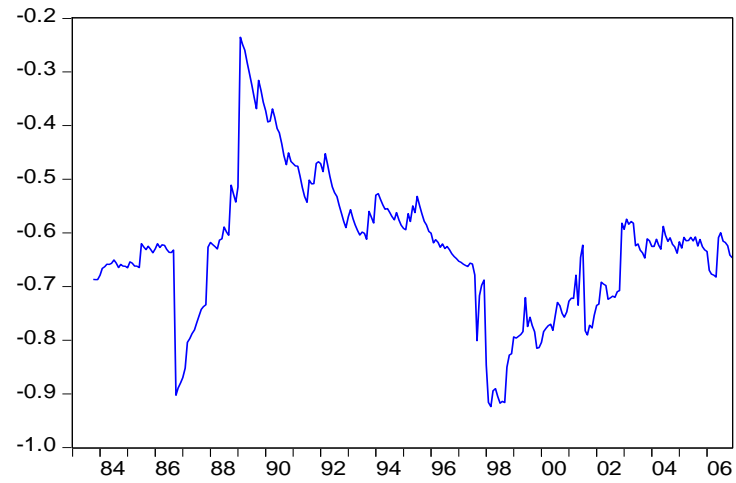

Malaysia

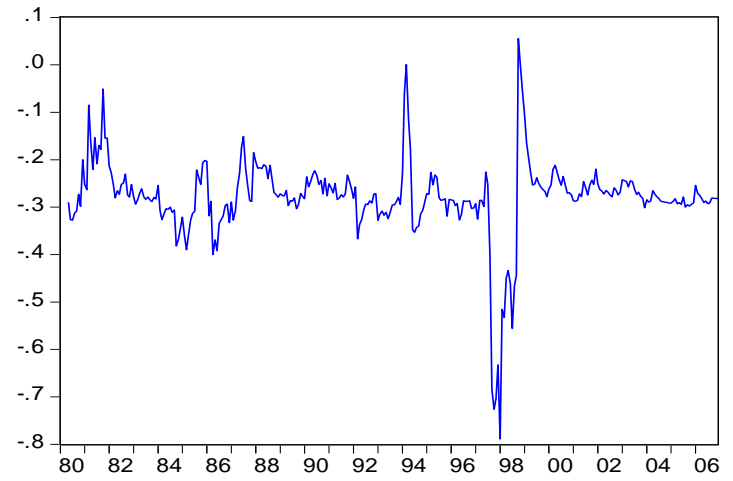

Singapore

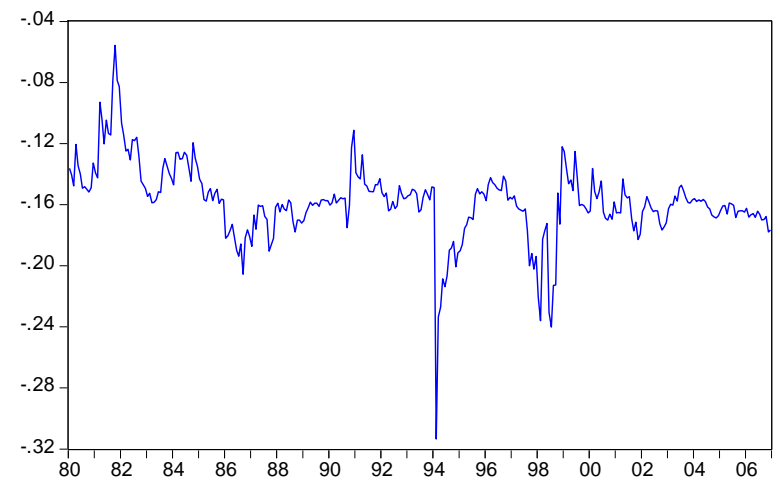

Korea

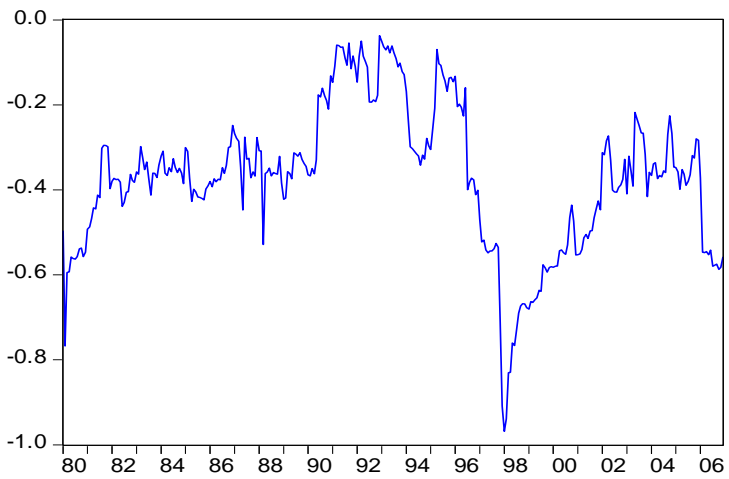

Philippines

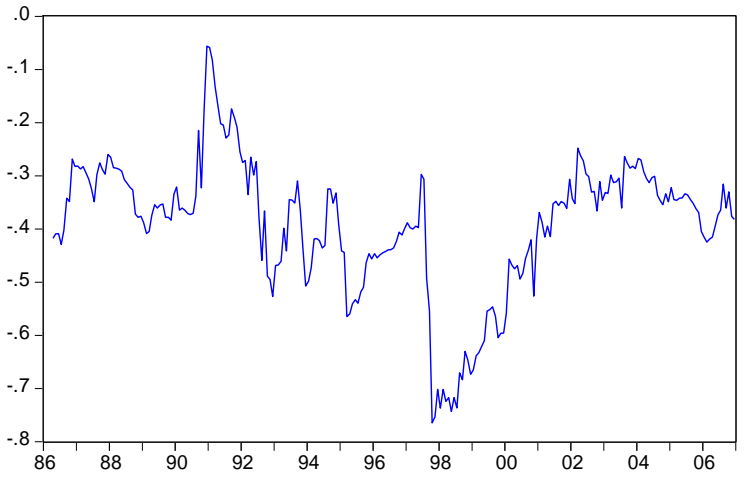

Thailand

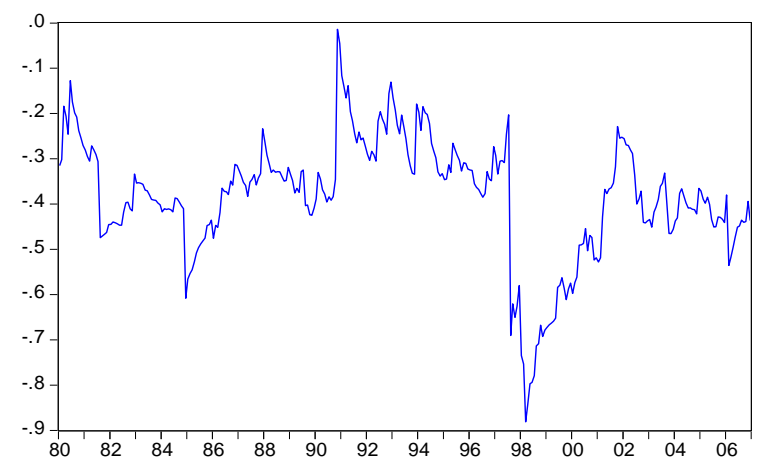




\section{b) Developed markets}

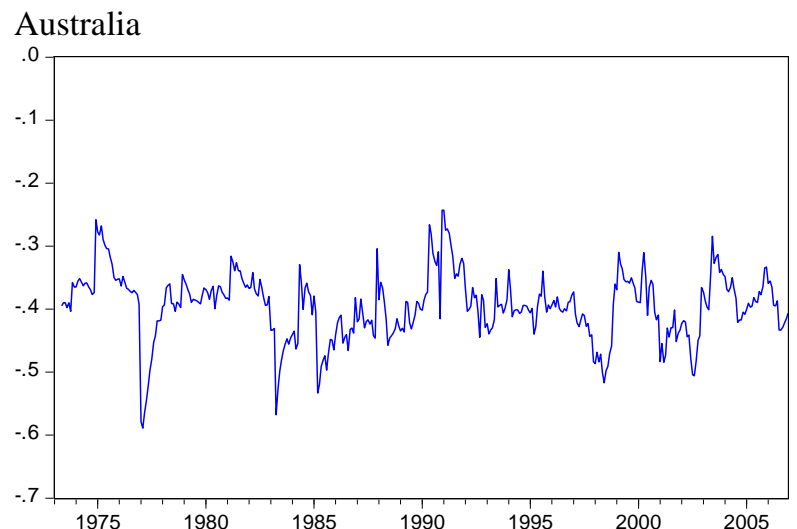

Canada

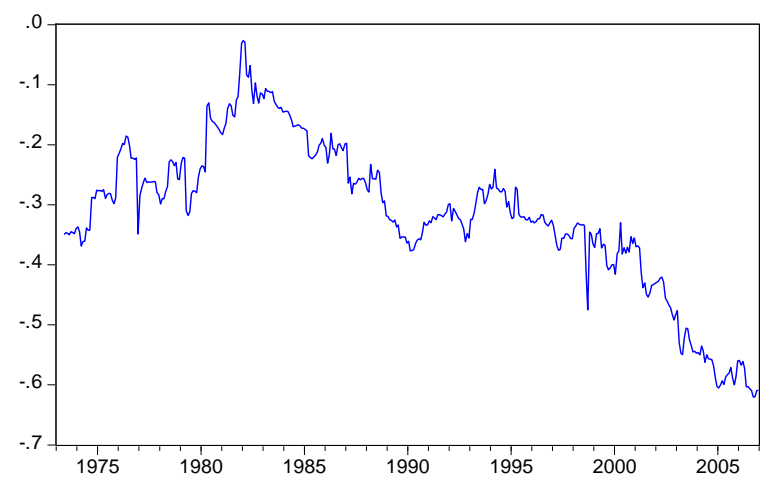

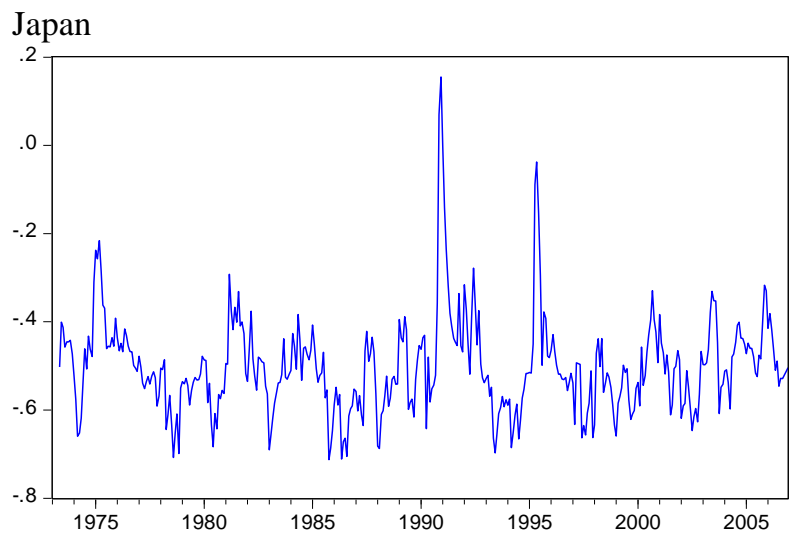

UK

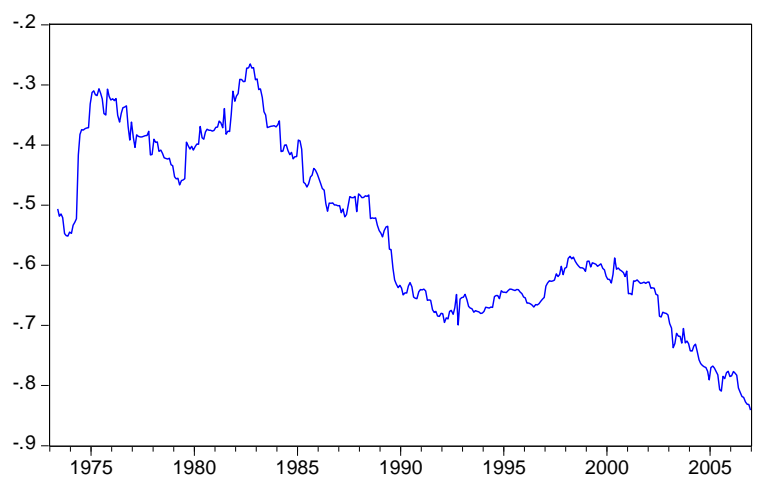

